\title{
Undifferentiated connective tissue disease presenting with vascular pattern of renal amyloidosis with carpel tunnel syndrome: A case report
}

\author{
Sham Sunder, Satyanand Sathi, Himanshu Mahapatra, Rajesh J, \\ Anurag Gupta, Prabhu K
}

\begin{abstract}
Introduction: The undifferentiated connective tissue disease (UCTD) is the clinical entity where the patients share the clinical symptoms of different connective tissue diseases but do not satisfy the classification criteria of the American College of Rheumatology for a particular connective tissue disease. Case Report: A 62-year-old female was presented with multiple joint pain, Raynaud's phenomenon, alopecia, swelling of legs, hardening of skin of the fingers of hands, and carpel tunnel syndrome. Antinuclear antibody test was moderately positive. Antibodies to double-stranded DNA and for antiphospholipid (lupus anticoagulant and anticardiolipin), anticentromere, antiScl-7o, Anti-Jo1, U1-RNP Anti-Ro/SSA, Anti-La/ SSB, were negative. RA factor was also negative. Twenty-four hour urine showed nephrotic range proteinuria and renal biopsy showed vascular pattern of renal amyloidosis with changes of interstitial fibrosis. The patient was diagnosed as having UCTD with vascular pattern of renal amyloidosis with carpel tunnel syndrome with
\end{abstract}

Sham Sunder ${ }^{1}$, Satyanand Sathi ${ }^{2}$, Himanshu Mahapatra ${ }^{3}$, Rajesh J², Anurag Gupta², Prabhu K

Affiliations: ${ }^{1}$ Professor, Department of Nephrology, PGIMER \& Dr. Ram Manohar Lohia Hospital New Delhi, India; ${ }^{2} D M$ Student, Department of Nephrology, PGIMER \& Dr. Ram Manohar Lohia Hospital New Delhi, India; ${ }^{3}$ Associate Professor, Department of Nephrology, PGIMER \& Dr. Ram Manohar Lohia Hospital New Delhi, India.

Corresponding Author: Satyanand Sathi, Department of Nephrology, PGIMER, Dr. RML Hospital, New Delhi, 110001, India; Email: satyanandsathi@yahoo.com

Received: 11 March 2014

Accepted: 22 March 2014

Published: 01 June 2014 nephrotic syndrome (NSAIDS induced minimal change nephropathy) with chronic kidney disease stage 3. Conclusion: Undifferentiated connective tissue disease may lead to renal involvement in the form of vascular pattern of renal amyloidosis. Raynaud's phenomenon and carpel tunnel syndrome both can, coexist and may herald inflammatory arthritis or an UCTD.

Keywords: Undifferentiated connective tissue disease, Vascular pattern of renal amyloidosis, Carpel tunnel syndrome

\section{How to cite this article}

Sunder S, Sathi S, Mahapatra H, Rajesh J, Gupta A, Prabhu K. Undifferentiated connective tissue disease presenting with vascular pattern of renal amyloidosis with carpel tunnel syndrome: A case report. Int J Case Rep Images 2014;5(6):417-422.

doi:10.5348/ijcri-201479-CR-1039o

\section{INTRODUCTION}

The undifferentiated connective tissue disease (UCTD) is the clinical entity where the patients share the clinical symptoms of different connective tissue diseases but do not satisfy the classification criteria of the American College of Rheumatology for a particular connective tissue disease such as rheumatoid arthritis, systemic sclerosis, Sjögren's syndrome, systemic lupus erythematosus, mix connective tissue disease, polymyositis or dermatomyositis $[1,2]$. The diagnostic criteria for UCTD, requires a positive antinuclear antibody test and disease duration of at least three years [1]. UCTD may be associated with Raynaud's phenomenon, arthralgia, and carpal tunnel syndrome [3]. Secondary amyloidosis is a result of chronic infection or inflammatory disease. 
Nephrotic syndrome (minimal change nephropathy) may be the manifestation of NSAIDS abuse.

\section{CASE REPORT}

A 62-year-old female was presented with a three-year history of bluish discoloration of fingers of both hands on cold exposure, thickening of skin of all the fingers of hands, inability to clench the fist, multiple joint pains and progressive hair loss of scalp. She had a two-year history of tingling and numbness of both hands and an eightmonth history of swelling of both lower limbs. Patient took on and off pain killers (NSAIDS) for joint pains for three years. Past history of diabetes, hypertension and family history of similar illness, were absent. On physical examination diffuse non-cicatrizing alopecia of scalp was present. Thickening and tightening of skin was present over the fingers of both hands (sclerodactyly). Motor system examination showed, bilateral wasting of thenar muscles of hands (Figure 1). Her laboratory profile is given in Table 1. Ultrasonography of abdomen showed right kidney $8.7 \times 2.9 \mathrm{~cm}$, left kidney $8.5 \times 2.8 \mathrm{~cm}$ with maintained

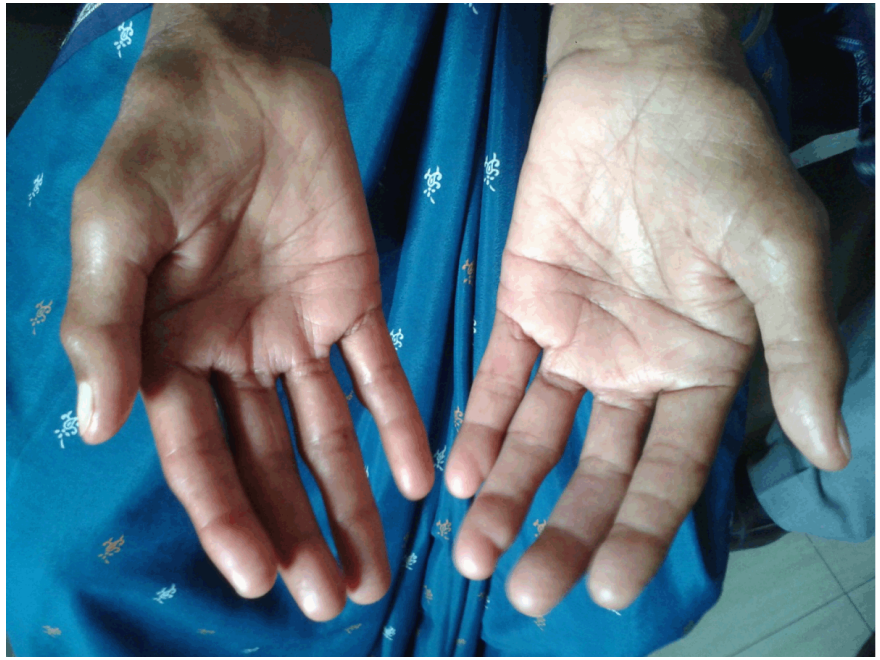

Figure 1: Patient showing carpel tunnel syndrome; claw hands with bilateral wasting of thenar muscles.

corticomedullary differentiation and increased cortical echogenicity. 2D-ECHO showed minimal pericardial effusion (ejection fraction 55\%). Nerve conduction

Table 1: Laboratory profile of patient

\begin{tabular}{|c|c|}
\hline Hemoglobin & $8.5 \mathrm{~g} / \mathrm{dL}$ \\
\hline TLC & $9300 / \mathrm{mm}^{3}$ \\
\hline Platelet count & 2.8 lakhs $/ \mathrm{mm}^{3}$ \\
\hline ESR & $90 \mathrm{~mm}$ \\
\hline Serum hs-CRP & $6.8 \mathrm{mg} / \mathrm{L}$ \\
\hline Blood urea & $69 \mathrm{mg} / \mathrm{dL}$ \\
\hline Serum creatinine & $\begin{array}{l}2.2 \mathrm{mg} / \mathrm{dL} \text { (base line) } \\
1.7 \mathrm{mg} / \mathrm{dL} \text { after } 6 \text { month follow up. }\end{array}$ \\
\hline Serum albumin and globulin & $2.8 \mathrm{mg} / \mathrm{dL}$ and $1.9 \mathrm{mg} / \mathrm{dL}$ \\
\hline Serum $C_{3}$ & $113 \mathrm{mg} / \mathrm{dL}(83-177 \mathrm{mg} / \mathrm{dL})$ \\
\hline Serum $\mathrm{C}_{4}$ & $22.8 \mathrm{mg} / \mathrm{dL}(16-47 \mathrm{mg} / \mathrm{dL})$ \\
\hline HBsAg/antiHCV/HIV 1,2 & Non reactive \\
\hline Serum protein electrophoresis & No M spike in gamma globulin region \\
\hline Serum free light chain assay (kappa/lambda) ratio & $\begin{array}{l}1.34[(0.37-3.1) \text { range in renal failure }] \\
{[(0.26-1.65) \text { range without renal failure }]}\end{array}$ \\
\hline Anti nuclear antibody & Positive (moderately) \\
\hline Anti-dsDNA & Negative \\
\hline Lupus anticoagulant/anticardiolipin $\mathrm{Ab}$ & Negative \\
\hline Anticentromere antibody & Negative \\
\hline Anti-Scl-70 & Negative \\
\hline Anti-Jo1 & Negative \\
\hline Anti-U1RNP & Negative \\
\hline Anti-Ro/SSA, Anti-La/SSB & Negative \\
\hline RA factor & Negative \\
\hline Urine routine and microscopy & $\begin{array}{l}\text { Protein } 3^{+} \text {, sugar nil, pH 6.5, WBCs 4-6/hpf, RBCs 1-2/ } \\
\text { hpf }\end{array}$ \\
\hline 24-hour urine protein & $\begin{array}{l}6.7 \mathrm{~g} / \text { day (base line) } \\
2.6 \mathrm{~g} / \text { day after } 2 \text { month follow-up } \\
226 \mathrm{mg} / \text { day after } 6 \text { month follow-up }\end{array}$ \\
\hline Urine for bence-jones protein & Negative \\
\hline
\end{tabular}


velocity showed, motor-sensory neuropathy of bilateral median nerve and peroneal nerve. Renal biopsy, on light microscopy (Figure 2) showed non-proliferative morphology in viable glomeruli, global glomerular sclerosis in 7/18 (38.8\%) glomeruli, secondary segmental tufts sclerosis in 2/18 (11.1\%) of sampled glomeruli, focal chronic tubulointerstitial nephritis (moderate severity), mild arterial fibrointimal sclerosis and focal deposition of congophilic material in arterial/arteriolar walls (Figure 3). Immunofluorescence examination showed, kappa light chains smudgy mesangial entrapment, lambda light chains smudgy mesangial entrapment but all immunoglobulins and complements were negative. The patient was diagnosed as having UCTD with vascular pattern of renal amyloidosis with carpel tunnel syndrome with nephrotic syndrome with chronic kidney disease stage 3 (Modification of Diet in Renal Disease, eGFR: $32 \mathrm{~mL} / \mathrm{mint} / 1.73$ meter square body surface area). In the view of UCTD, the patient was started on low dose prednisolone $20 \mathrm{mg} /$ day, hydroxychloroquine $200 \mathrm{mg}$ twice a day, and low dose diuretic with calcium and vitamin D supplements. Prednisolone was tapered to $10 \mathrm{mg} /$ day after completion of two months. Patient responded symptomatically and proteinuria decreased to $2.6 \mathrm{~g}$ /day from $6.7 \mathrm{~g} /$ day within two months. At sixmonth follow-up proteinuria was $226 \mathrm{mg} /$ day and creatinine was $1.7 \mathrm{mg} / \mathrm{dL}$.

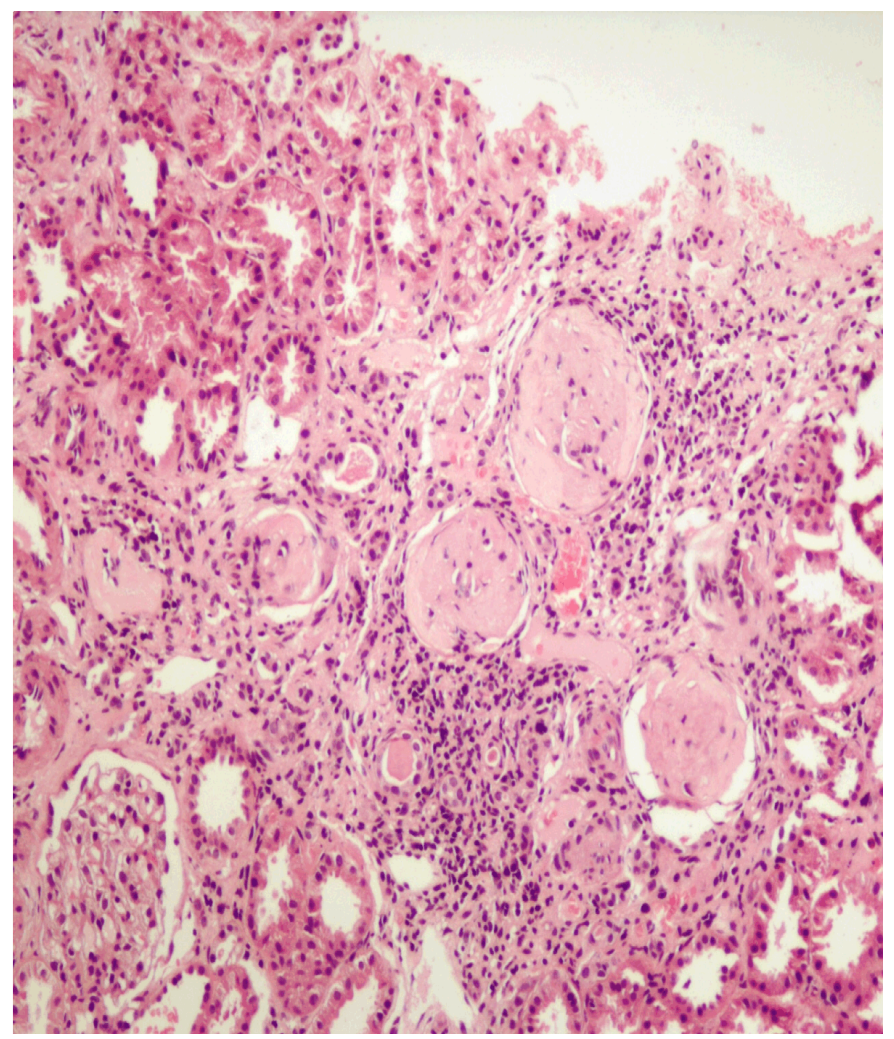

Figure 2: Kidney biopsy specimen showing focal chronic tubulointerstitial nephritis, global glomerular sclerosis and non-proliferative morphology in viable glomeruli.
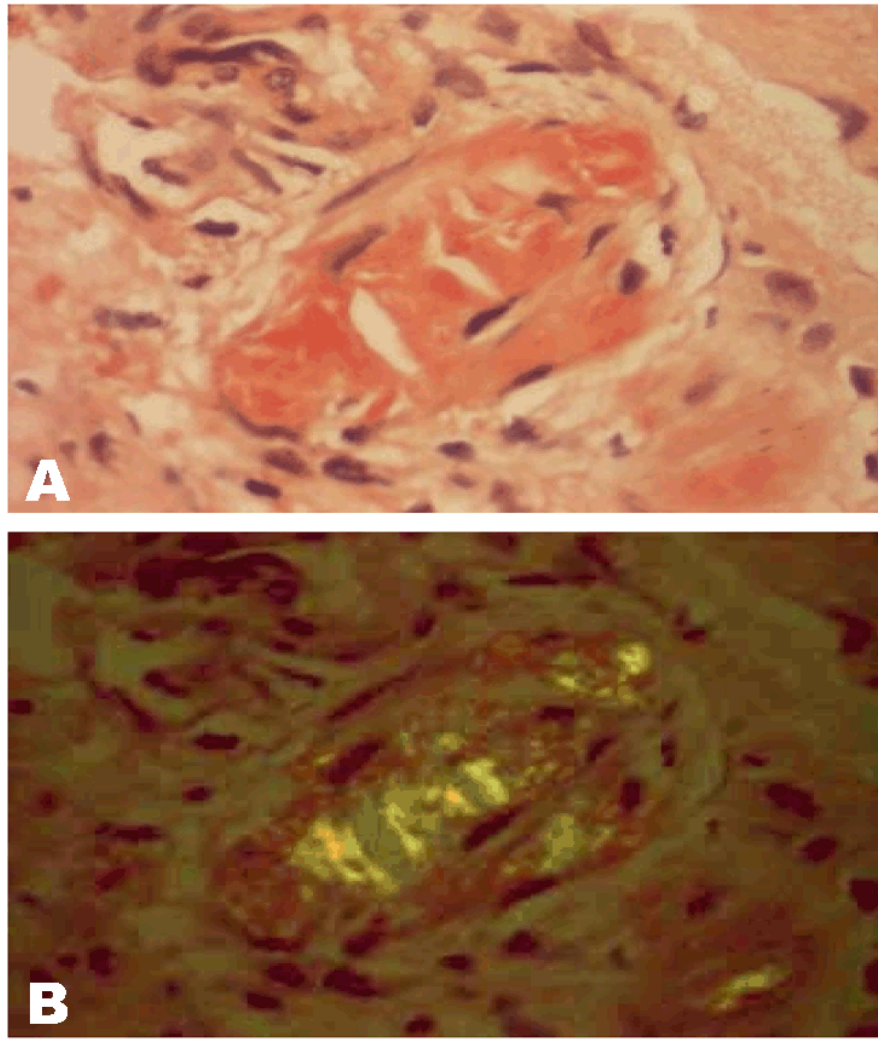

Figure 3: Kidney biopsy specimen (A) Arterial/arteriolar wall with focal deposition of congophilic material (Congo Red stain, x400), (B) Arterial/ arteriolar wall with focal deposition of congophilic material showing greenish birefringence (Congo Red stain under Polarized light, x400).

\section{DISCUSSION}

The clinical features and laboratory profile of our case patient is suggestive of some systemic connective tissue disease but this patient does not fit in to the specific single connective tissue disease according to the classification criteria of the American College of Rheumatology. This type of clinical picture is presently classified as UCTD $[1,2]$. Approximately, $20-40 \%$ of patients who have an undifferentiated diagnosis at onset, may develop a well defined particular CTD in long-term follow-up [4, 5].This differentiation is generally completed after 5 to 10 years of the disease onset [4, 5]. Chronic (autoimmune) inflammatory disease is the most common cause $(42.6 \%$ cases) of secondary renal amyloidosis or AA amyloidosis [6]. In renal amyloidosis, amyloid deposits may be found in different distribution patterns within the kidney compartments. The amyloid deposition occurs most commonly in glomerular compartment, approximately in $80 \%$ of the cases. The vascular pattern of renal amyloidosis may be found in $12.5-39 \%$ of cases [6]. In vascular pattern of renal amyloidosis, amyloid deposits are seen usually within arteries or arterioles [6]. Renal biopsy of case patient showed that viable glomeruli were unremarkable and did not show evidence of amyloid/ 
congophilic material deposition but occasional arteries/ arterioles showed amorphous congophilic material which showed greenish birefringence in congo red stained sections, viewed under polarized light indicating amyloid deposition. In our patient, chronic (autoimmune) inflammatory disease that is UCTD is the possible cause of vascular pattern of renal amyloidosis. Another likely diagnostic possibility would include a podocytopathy (minimal change nephropathy) contributing to proteinuric illness, associated with pain killers (NSAIDS) for three years for rheumatological symptoms. Carpal tunnel syndrome (CTS) is an inflammatory disorder. It is a common entrapment neuropathy of median nerve. The mechanism of median nerve compression is presumably pressure in the carpal tunnels due to inflammatory changes. Like Raynaud's phenomenon, CTS can occasionally herald inflammatory arthritis or a connective tissue disorder . Indeed, many patients with CTS may have an associated Raynaud's phenomenon [7].

\section{CONCLUSION}

Undifferentiated connective tissue disease (UCTD) could be viewed as a distinct systemic autoimmune disease with a characteristic clinical and serological profile. It may lead to renal involvement in the form of vascular pattern of renal amyloidosis. Raynaud's phenomenon and carpel tunnel syndrome both can, coexist and may herald inflammatory arthritis or an UCTD.

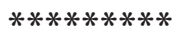

\section{Author Contributions}

Sham Sunder - Substantial contributions to conception and design, Acquisition of data, Drafting the article, Revising it critically for important intellectual content, Final approval of the version to be published

Satyanand Sathi - Substantial contributions to conception and design, Analysis and interpretation of data, Drafting the article, revising it critically for important intellectual content, Final approval of the version to be published Himanshu Mahapatra - Substantial contributions to conception and design, Revising it critically for important intellectual content, Final approval of the version to be published

Rajesh J - Substantial contributions to conception and design, Drafting the article, Final approval of the version to be published

Anurag Gupta - Substantial contributions to conception and design, Revising it critically for important intellectual content, Final approval of the version to be published Prabhu K - Substantial contributions to conception and design, Drafting the article, Final approval of the version to be published

\section{Guarantor}

The corresponding author is the guarantor of submission.

\section{Conflict of Interest}

Authors declare no conflict of interest.

\section{Copyright}

(C) 2014 Sham Sunder et al. This article is distributed under the terms of Creative Commons Attribution License which permits unrestricted use, distribution and reproduction in any medium provided the original author(s) and original publisher are properly credited. Please see the copyright policy on the journal website for more information.

\section{REFERENCES}

1. Mosca M, Neri R, Bombardieri S: Undifferentiated connective tissue diseases (UCTD): a review of the literature and a proposal for preliminary classification criteria. Clin Exp Rheumatol 1999, 17:615-620.

2. Bodolay E, Csiki Z, Szekanecz Z, Ben T, Kiss E, Zeher M, Szücs G, Dankó K, Szegedi G: Five-year followup of 665 Hungarian patients with undifferentiated connective tissue diseases (UCTD). Clin Exp Rheumatol 2003, 21:313-320.

3. Herrick AL. Rheumatology 2005 44: 587-96. Denton CP. and Black CM. Ballieres Clinical Rheum 2000; 14: $17-35$.

4. Alarcon GS. Unclassified or undifferentiated connective tissue disease. Baillieres Best Practice Clin Rheumatol ;A good review of the 10-year clinical outcomes in UCTD. 2000 Mar;14(1):125-37.

5. Mosca M Best Pract Res Clin Rheumatol et al. Undifferentiated connective tissue diseases (UCTD): a new frontier for rheumatology. (2007), 21: 10111123

6. Helmut Hopfer, Thorsten Wiech and Michael J. Mihatsch: Renal amyloidosis revisited: amyloid distribution, dynamics and biochemical type, Nephrol Dial Transplant (2011) 26: 2877-2884

7. Pal B, Keenan J, Misra HN, Morris J, et al. Raynaud's phenomenon and carpal tunnel syndrome [Abstract]. BrJ Rheumatol 1990 September (Suppl). 


\section{ABOUT THE AUTHORS}

Article citation: Sunder S, Sathi S, Mahapatra H, Rajesh J, Gupta A, Prabhu K. Undifferentiated connective tissue disease presenting with vascular pattern of renal amyloidosis with carpel tunnel syndrome: A case report. Int J Case Rep Images 2014;5(6):417-422.

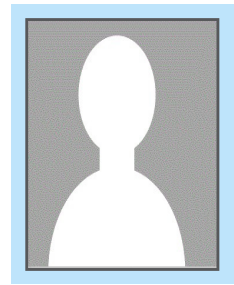

Sham Sunder is Professor, Head of the Department and Director of Department of Nephrology, PGIMER, Dr RML Hospital, New Delhi, India. He is a renowned indian Nephrologist and is a great teacher. His area of interest include intervention nephrology and renal transplantation.

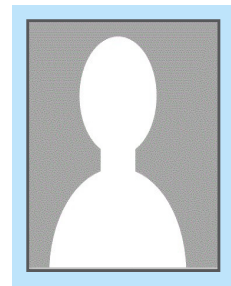

Satyanand Sathi is final year DM Resident in Department of Nephrology, PGIMER, Dr RML Hospital, New Delhi, India. His area of interest include clinical nephrology. He intends to peruse a fellowship in renal transplantation after completing DM nephrology.

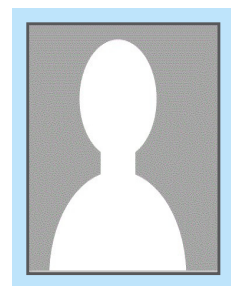

Himanshu Mahapatra is Associate Professor in Department of Nephrology, PGIMER, Dr RML Hospital, New Delhi, India. His area of interest include clinical nephrology and arteriovenous fistula surgeries.

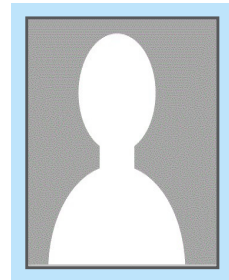

Rajesh J is final year DM Resident in Department of Nephrology, PGIMER, Dr RML Hospital, New Delhi, India. His area of interest include clinical nephrology. He intends to peruse a fellowship in renal transplantation after completing DM nephrology.

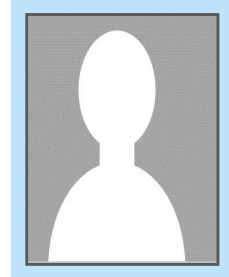

Anurag Gupta is second year DM Resident in Department of Nephrology, PGIMER, Dr RML Hospital, New Delhi, India. His area of interest include clinical nephrology. He intends to peruse a fellowship in intervention nephrology after completing DM nephrology.

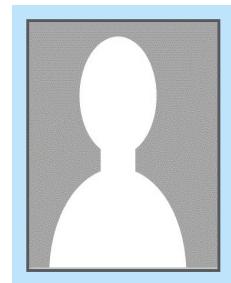

Prabhu K is second year DM Resident in Department of Nephrology, PGIMER, Dr RML Hospital, New Delhi, India. His area of interest include clinical nephrology. He intends to peruse a fellowship in intervention nephrology after completing DM nephrology. 
Access full text article on other devices

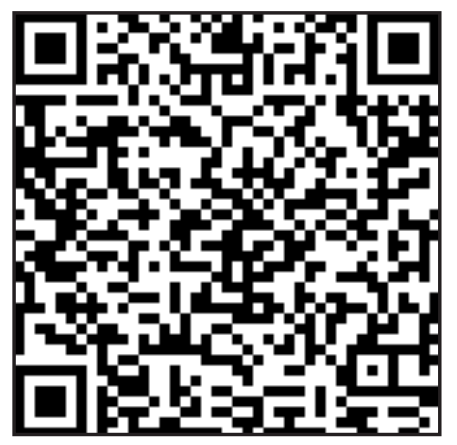

Access PDF of article on other devices

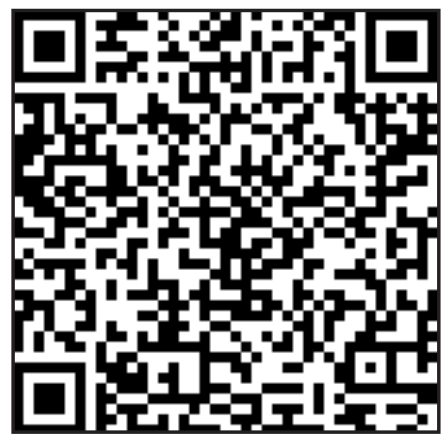

